\title{
Metal contamination and fractionation in sediments from the lower basin of the Vale do Ribeira (SE, Brazil)
}

\author{
Estefanía Bonnail 1 • Lucas M. Buruaem • \\ Lucas G. Morais • Denis M. S. Abessa • \\ Aguasanta M. Sarmiento • T. Ángel DelValls
}

Received: 2 December 2016 / Accepted: 21 April 2017 /Published online: 1 May 2017

(C) Springer International Publishing Switzerland 2017

\begin{abstract}
The sediment quality of Ribeira de Iguape River is affected by former $\mathrm{Pb}$ extraction mining. Some studies affirm the restoration status of the basin, however, mobility of metals and its associated risk is still questioned. This study integrates the metal concentrations in the lower part of the basin with different contamination source to determine the existence of risks associated with the mobile fractions of the geochemical matrix. Despite concentrations of metals were low and the environmental risk factor values were negative, our results indicated that $\mathrm{As}, \mathrm{Mn}, \mathrm{Pb}$, and $\mathrm{V}$ were present in the most labile forms. The multivariate analysis conducted using metal concentrations, environmental risk factor values and speciation suggested that any risk would be associated with the labile fractions of the
\end{abstract}

E. Bonnail $(\bowtie)$

Centro de Investigaciones Costeras-Universidad de Atacama (CIC-UDA), Av/ Copayapu n ${ }^{\circ} 85$, Copiapó, Chile e-mail: estefania.bonnail@uda.cl

L. M. Buruaem • L. G. Morais · D. M. S. Abessa Campus Experimental do Litoral Paulista, Núcleo de Estudos sobre Poluição e Ecotoxicologia Aquática, Universidade Estadual Paulista "Júlio de Mesquita Filho", Praça Infante Dom Henrique, s/n, São Vicente, SP 11330-900, Brazil

A. M. Sarmiento

Department of Earth Sciences, Faculty of Experimental Sciences, University of Huelva, Campus 'El Carmen', 21071 Huelva, Spain

T. Á. DelValls

UNESCO UNITWIN/WiCop. Department of Physical-Chemistry. Faculty of Marine and Environmental Sciences, University of Cádiz, Campus Río San Pedro Puerto Real, 11510 Cádiz, Spain analyzed elements, especially for $\mathrm{Pb}$. The station from Registro was stressed by $\mathrm{Co}, \mathrm{Pb}$ and $\mathrm{Zn}$; with $\mathrm{Pb}$ under the reactive fraction that could be associated with high mobility and potential bioavailability.

Keywords Iguape River · Metal monitoring · Environmental risk assessment $\cdot$ Sequential extraction

\section{Introduction}

The Vale do Ribeira is located on the Southeast of Brazil, between Paraná and São Paulo states; it takes place in very preserved region, which is considered the Atlantic rainforest reserve of the biosphere and connects to the World Natural Heritage site of the CananéiaIguape Estuarine Complex. Its fluvial network was historically affected by former mining activities of lead extraction, especially the Ribeira de Iguape River (RIR). Although extraction activities ceased in the 1990s, tailing residues located on the upper part of the basin still represent sources of metals to the aquatic system (Cunha et al. 2005). Latest investigations have determined that the basin is under a restoration process since the metals inputs have decreased and the trawling of metals associated with particulate matter towards the Atlantic Ocean (Cunha et al. 2005; Abessa et al. 2012, 2014). Nevertheless, few studies have undertaken the process in the lower part of the basin, where the deposition of sediments and particles occur and the mobility of metals could be linked to potential toxic risks. 
The potential risk of elements is link to the chemical form in the environment, which is governed by physicochemical parameters (Hamelink et al. 1994). Therefore, the chemical form can vary with climatic phenomena and other hydrological events in aquatic systems. Due to that, the assessment of the ecological risk is associated with the chemical fractionation. The sequential extraction procedures are widely accepted as appropriate methods for assessing the speciation of metals in sediments (Tessier et al. 1979; Kestern and Förstner 1986). Metals bound to the first fractions are considered more susceptible to remobilization than metals residing in the lattices of sediment minerals (Luoma and Davis 1983; Riba et al. 2002a).

The results presented in this work are part of an integrative approach conducted in the area to assess the sediment quality. The main objective of this research is to determine the possible risks associated with metals and metalloids in the lower RIR, considering the mobility of these elements. To achieve that, the concentration of some elements ( $\mathrm{Al}, \mathrm{As}, \mathrm{B}, \mathrm{Ba}, \mathrm{Be}, \mathrm{Ca}, \mathrm{Co}, \mathrm{Cr}, \mathrm{Cu}, \mathrm{Fe}$, $\mathrm{Li}, \mathrm{Mg}, \mathrm{Mn}, \mathrm{Ni}, \mathrm{Pb}, \mathrm{Sr}, \mathrm{Ti}, \mathrm{U}, \mathrm{V}$, and $\mathrm{Zn}$ ) was assessed plus the geochemical fractionation in sediment determined by means of a chemical fractionation analysis using a sequential extraction procedure. The potential environmental risk was calculated based on freshwater sediment quality benchmarks, and integrated to understand potential risk associated with mobility of metals in the lower part of the basin.

\section{Materials and methods}

The geomorphology of the valley has been demonstrated as a crucial factor (Abessa et al. 2014) for the deposition of contaminants in the lower part of the river (Moraes et al. 2004) as the river leaves the sloppy zone and starts flowing through a plain area. This sink effect is also incremented by the meanders formation in the flooding plain, sequestering contaminants in elbows. Sediment sampling stations were situated in the lower part of the RIR basin (Fig.1): Sete Barras (SB; 24 ${ }^{\circ} 23^{\prime}$ $16^{\prime \prime} \mathrm{S}, 47^{\circ} 55^{\prime} 33^{\prime \prime} \mathrm{W}$ ) and Registro (REG; $24^{\circ} 29^{\prime} 15^{\prime \prime} \mathrm{S}$, $\left.47^{\circ} 50^{\prime} 37^{\prime \prime} \mathrm{W}\right)$. SB is located closer to the mining discharges; it is also characterized with strong flooding episodes. In contrast, REG is affected by flooding episodes of many tributaries. Superficial sediment samples were manually collected from the river banks and transported in dark conditions into plastic recipients with a layer of water from the adjacent river. A third
Fig. 1 Map of the sampling sites in the lower basin of the Iguape River in the Vale do Ribeira and the sampling site in the Rio Douro in the Ecological Park Perequê
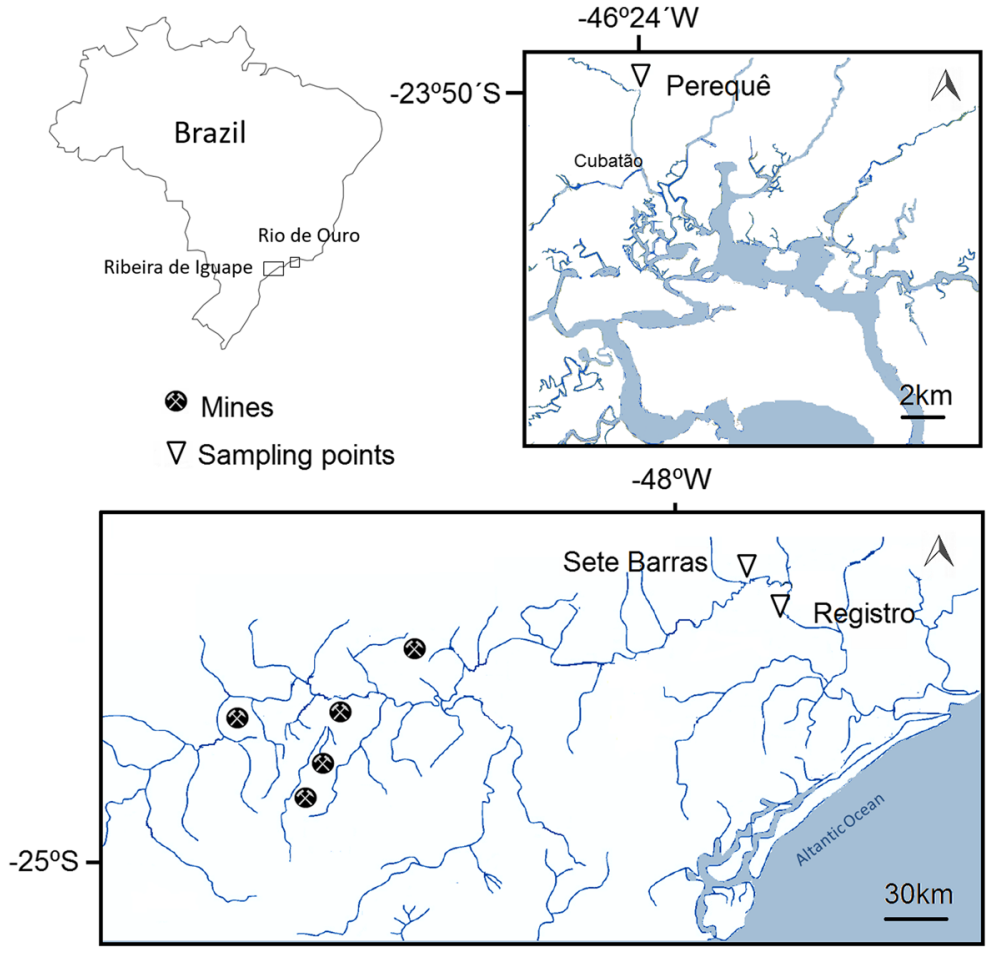
sediment sampling site was selected as reference site from the Rio de Ouro (Cubatão, São Paulo) in the Ecological Park of Perequê (EPP; $23^{\circ} 50^{\prime} 29^{\prime \prime}$ S, $46^{\circ}$ $24^{\prime} 57^{\prime \prime} \mathrm{W}$ ).

Sediment samples were dried at $60^{\circ} \mathrm{C}$, homogenized in mills and then analyzed for the total organic carbon (TOC), nitrogen $(\mathrm{N})$, and sulfur (S) by using an elemental analyzer model Vario MACRO Cube. The pseudototal digestion of sediments was performed following the International Organization for Standardization (ISO) standard procedure 11466 (1995). The chemical partitioning of metals in sediment was studied by the modified Bureau Community of Reference (BCR) sequential extraction procedure. An initial step, performed with Milli-Q water as reagent, yielded the most soluble fraction (F0); acetic acid was employed as exchangeable fraction and bound to carbonates (F1); the reducible fraction (F2) bound to the Mn-Fe oxides was extracted with hydroxylammonium chloride; the oxidizable (F3) considered as the fraction bound to organic matter and sulfides was determined with peroxide and ammonium acetate; and the last step with aqua regia digestion, yielded the residual fraction (F4). The sediment digestion procedure and analytical procedures are detailed in Bonnail et al. (2016). The trace metal analysis of major and trace elements of solutions took place by means of an Agilent Technologies 7700 Series inductively coupled plasma mass spectrometer (ICP-MS) and an Iris Intrepid Model atomic emission spectroscopy (ICP-AES) by the certified SC-ICYT. To demonstrate the reproducibility of the results, the analysis sequences consisted of calibration standards, standard solutions analyzed as an unknown (quality control solutions), method blanks, and the certified reference material BCR-701 for sediment-extractable trace elements. Furthermore, an internal check was performed on the sequential extraction by comparing the total amount of elements extracted by different reagents during the sequential extraction procedure with the results of the pseudo-total digestion: $\left[\left(C_{\mathrm{F} 0}+C_{\mathrm{F} 1}+C_{\mathrm{F} 2}+C_{\mathrm{F} 3}+C_{\mathrm{F} 4}\right) /\right.$ $\left.C_{\text {Pseudototal digestion }}\right] \times 100$.

The ecological risk factor (ERF) was calculated as outline in Riba et al. (2002b) based on the metal concentration of each metal $\left(C_{\mathrm{i}}\right)$. The $C_{\mathrm{SQV}}$ concentrations used in this study were the freshwater sediment quality thresholds of the USEPA. These values are widely used all over the world as sediment guidelines, as due to there is a consensus that they are effective to predict sediment toxicity to biota, based on chronic direct exposure, and/ or non-lethal endpoint studies designed to be protective of sensitive species (Pluta 2006; Hübner et al. 2009).

$\mathrm{ERF}=\frac{C_{\mathrm{i}}-C_{\mathrm{SQV}}}{C_{\mathrm{SQV}}}$

A cluster analysis (Ward's method) was applied to the set original set of variables of sediment characterization (textural distribution, N, S, H, organic matter$\mathrm{OM}$, total organic content-TOC), the total metal concentrations, the environmental risk factors (ERF) calculated for toxic elements (standardized as the percentage of deviation) and the concentrations of metal(loid)s in mobile (M) and residual form (R). According to Mooi and Sarstedt (2011), cluster analyses have no requirements of minimum size samples and, thus, it could be used in our study. Statistical analyses were performed with the aid of the statistical software PAST 1.34 for Windows (Hammer et al. 2001).

\section{Results and discussion}

Table 1 shows the sediment characterization of the sediment samples and the total metal concentrations in the collected sediments from the lower basin of the RIR and the Ecological Park Perequê (EPP). Sandy sediments were predominant in SB (98\%) and EPP (99\%) with lower concentration of organic matter (1.40 and $0.60 \%$, respectively). In contrast, the station REG displayed greater percentage of fines $(14 \%)$ and greater organic matter (1.60\%). The TOC was slightly higher in the RIR than in EPP.

Table 1 also shows the results of the calculated ERF for the studied area and all the elements. Positive values of ERF indicate about adverse effects associated with the metal (Riba et al. 2002b). However, no positive value was obtained in the current study which is pointing any risk associated with the metal concentrations in the sediment SB, REG, and EPP. Nevertheless, it is possible to rank the elements according to the ERF values obtained and associated with the element enrichment in each station:

$\mathrm{SB}: \mathrm{Mn}>\mathrm{Pb}>\mathrm{Zn}>\mathrm{Ni}>\mathrm{Cu}>\mathrm{Co}>\mathrm{Fe}>\mathrm{Cr}>\mathrm{As}$

$\mathrm{REG}: \mathrm{Mn}>\mathrm{Pb}>\mathrm{Zn}>\mathrm{Ni}>\mathrm{Cu}>\mathrm{Co}>\mathrm{Fe}>\mathrm{Cr}>\mathrm{As}$

$\mathrm{EPP}: \mathrm{Fe}>\mathrm{Ni}>\mathrm{Zn}>\mathrm{Mn}>\mathrm{Cr}>\mathrm{Cu}>\mathrm{Pb}>\mathrm{Co}>\mathrm{As}$

The sequences of the stations from the RIR are homologous, but the lower values attributed to $\mathrm{Mn}$ displayed greater ERF values associated with a stronger 
Table 1 Sediment characterization as textural and organic matter $(\mathrm{OM})$, total organic content (TOC), nitrogen $(\mathrm{N})$, hydrogen $(\mathrm{H})$, and sulfurs (S) expressed in percentage, and metal and metalloid concentrations in the sediment samples (in $\mathrm{mg} / \mathrm{kg}$ dried weight) from the study stations. Environmental risk factors (ERF) calculated for the concentrations of the study (expressed in percentage)

\begin{tabular}{|c|c|c|c|c|c|c|c|}
\hline & \multirow[t]{2}{*}{ SB } & \multirow[t]{2}{*}{ REG } & \multirow[t]{2}{*}{ EPP } & & \multicolumn{3}{|c|}{$\operatorname{ERF}(\%)$} \\
\hline & & & & & SB & REG & EPP \\
\hline Sand & 98.2 & 85.8 & 99.5 & & & & \\
\hline Fines & 1.83 & 14.3 & 0.47 & & & & \\
\hline OM & 1.40 & 1.60 & 0.60 & & & & \\
\hline TOC & 0.68 & 0.44 & 0.30 & & & & \\
\hline $\mathrm{N}$ & 0.06 & 0.09 & 0.05 & & & & \\
\hline $\mathrm{H}$ & 0.25 & 0.25 & 0.28 & & & & \\
\hline $\mathrm{S}$ & 2061 & 0.90 & 1163 & & & & \\
\hline $\mathrm{Al}$ & 2903 & 3732 & 10,576 & & & & \\
\hline As & 0.56 & 0.63 & 1.31 & As & -0.94 & -0.94 & -0.87 \\
\hline B & 4.84 & 0.37 & 0.10 & & & & \\
\hline $\mathrm{Ba}$ & 41.6 & 63.1 & 42.1 & & & & \\
\hline $\mathrm{Be}$ & 0.38 & 0.38 & 0.33 & & & & \\
\hline $\mathrm{Ca}$ & 643 & 941 & 130 & & & & \\
\hline $\mathrm{Co}$ & 6.67 & 6.75 & 4.62 & $\mathrm{Co}$ & -0.87 & -0.86 & -0.91 \\
\hline $\mathrm{Cr}$ & 3.26 & 3.55 & 11.1 & $\mathrm{Cr}$ & -0.92 & -0.92 & -0.75 \\
\hline $\mathrm{Cu}$ & 4.67 & 6.21 & 7.32 & $\mathrm{Cu}$ & -0.85 & -0.80 & -0.77 \\
\hline $\mathrm{Fe}$ & 2045 & 2480 & 10,071 & $\mathrm{Fe}$ & -0.90 & -0.88 & -0.50 \\
\hline $\mathrm{Li}$ & 1.32 & 2.35 & 6.01 & & & & \\
\hline $\mathrm{Mg}$ & 1089 & 2155 & 3993 & & & & \\
\hline $\mathrm{Mn}$ & 394 & 362 & 129 & $\mathrm{Mn}$ & -0.14 & -0.21 & -0.72 \\
\hline $\mathrm{Ni}$ & 5.37 & 6.78 & 7.46 & $\mathrm{Ni}$ & -0.76 & -0.70 & -0.67 \\
\hline $\mathrm{Pb}$ & 10.1 & 18.9 & 3.87 & $\mathrm{~Pb}$ & -0.72 & -0.47 & -0.89 \\
\hline $\mathrm{Sr}$ & 4.49 & 7.48 & 1.18 & & & & \\
\hline $\mathrm{Ti}$ & 26.0 & 42.0 & 215 & & & & \\
\hline $\mathrm{U}$ & 0.28 & 0.48 & 0.26 & & & & \\
\hline V & 1.82 & 1.77 & 8.00 & & & & \\
\hline $\mathrm{Zn}$ & 29.7 & 47.4 & 34.4 & $\mathrm{Zn}$ & -0.75 & -0.61 & -0.72 \\
\hline
\end{tabular}

enrichment of this metal against the rest of the metals. Lead displayed the greatest ERF in the lower part of the RIR. In contrast, the greatest ERF in sediments from station EPP was associated with Fe. The enrichment in Fe is usually associated with industrial contamination, in this case likely to atmospheric dispersion and deposition from a major steel plant located in Cubatão.

To establish the potential bioavailability of the elements in the studied sediments, a chemical fractionation of the total concentration was conducted. Figure 2 shows the results of the metal(loid) fractionation according to the sequential extraction procedure for the stations SB, REG, and EPP. The total sum of elements contents in the mobile fraction $(\mathrm{M}=\Sigma \mathrm{F}(0-3))$ seems to be more bioavailable (Pérez-López et al. 2008) and with potential toxicity and hazardous for the environment (Vives et al. 2007). Meanwhile, elements collected in the residual fraction $(\mathrm{R}=\mathrm{F} 4)$ are associated with the lithological form considered less reactive and less bioavailable. The most bioavailable form of the elements bonds to the most labile fractions (F0, F1, and F2).

The concentration of elements in sediment from the station EPP (Al, Ba, Co, Cr, Cu, Fe, Li, Mg, Mn, Ni, Ti, and $\mathrm{Zn}$ ) was mainly associated with the residual fraction (F4 $>50 \%$ ), indicating that they were as nonbioavailable form. In contrast, the elements extracted from sediment of the RIR (As, B, Ba, Be, Ca, Co, Fe, $\mathrm{Mn}, \mathrm{Pb}$, and $\mathrm{V}$ ) presented a higher concentration associated with the most labile forms ( $\Sigma \mathrm{F} 0-2)$. What is more, the metal mobility was greater in SB than in REG. The main elements extracted were $\mathrm{Al}(\sim 37 \%$ in $\mathrm{SB}$ and EPP; and $33 \%$ in REG) and $\mathrm{Fe}(\sim 25 \%$ in sediments from RIR; and 35\% in EPP) in relative abundance, followed by $\mathrm{Mg}, \mathrm{Ca}$ in the RIR. In spite of the high concentration of $\mathrm{Fe}$ and $\mathrm{Al}$, they were below the guidelines of the USEPA (Table 1). On the other hand, the averaged As concentrations of RIR registered 0.60 and $1.31 \mathrm{mg} / \mathrm{kg}$ As in EPP, it was mainly presented as reducible fraction for both cases. Cd contamination was not detected for any of the sediment samples in the studied sites. Cr concentration in EPP was slightly greater than in RIR (11 and $3 \mathrm{mg} / \mathrm{kg} \mathrm{Cr}$, respectively), however in this last, it was presented under a greater mobile form $(>50 \%)$. There was a slight increment of $\mathrm{Cu}$ concentration close to the mouth of the RIR $(6.21 \mathrm{mg} / \mathrm{kg} \mathrm{Cu}$ in REG) in comparison with watersupstream in $\mathrm{SB}(4.67 \mathrm{mg} / \mathrm{kg} \mathrm{Cu})$; both sites almost exceeded half of the concentration as bioavailable form. In contrast, most of the $\mathrm{Cu}$ concentration found in EPP sediments $(7.32 \mathrm{mg} / \mathrm{kg} \mathrm{Cu})$ was extracted from the residual fraction (Fig.2).

Lead, the characteristic element mining discharges in $\mathrm{RIR}$, has been recognized as tracer of the environmental status of the basin by many authors (Charalampides and Manoliadis 2002; Moraes et al. 2004; Abessa et al. 2014; Nakata et al. 2017). The mobility of Pb close to the abandoned mines corresponds to the release kinetics data fitting to parabolic equations of diffusion, greater associated with the first phase (Buschle et al. 2010). The 
$\square F 0+1 \square F 2 \backsim F 3 \quad \square F 4$

$\square F 0+1 \square F 2 \square F 3 \square F 4$

SB
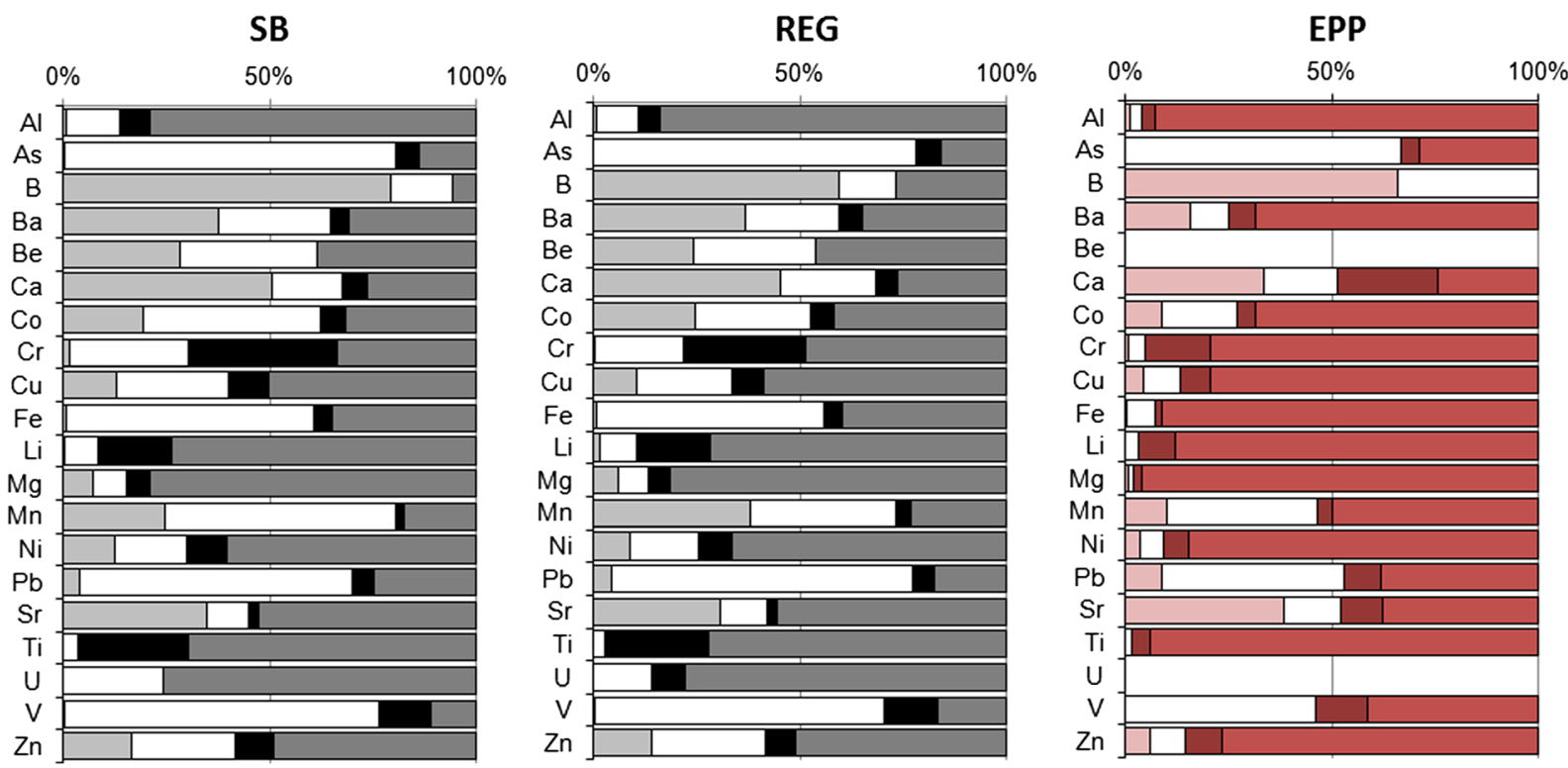

Fig. 2 Metal fractionation in four geochemical fractions (F0 + 1: water soluble; F2: exchangeable; F3: iron and manganese hydroxides; F4: residual fraction) for the sediment samples in the RIR (SB and REG) and the Ecological Park of Perequê (EPP)

concentration of $\mathrm{Pb}$ found in sediments from $\mathrm{SB}$ was the triple $(10.12 \mathrm{mg} / \mathrm{kg} \mathrm{Pb})$ and in REG supposed six-times $(18.88 \mathrm{mg} / \mathrm{kg} \mathrm{Pb})$ the concentration found in sediments from station EPP $(3.89 \mathrm{mg} / \mathrm{kg} \mathrm{Pb})$; this might be indicative of an anthropogenic contamination. Nevertheless, the background $\mathrm{Pb}$ level reported by Lopes (2007) is $25 \mathrm{mg} / \mathrm{kg} \mathrm{Pb}$. Despite of Pb has been historically the main contaminant of interest of RIR, concentrations in SB and REG did not exceed the TEL values of the USEPA, but they are characterized by a high mobility $(\Sigma \mathrm{F}(0-3)>70 \%)$. In contrast, previous studies found greater concentrations: $90 \mathrm{mg} / \mathrm{Kg} \mathrm{Pb}$ in REG (Moraes et al. 2004),

As a result, the concentrations of toxic elements in the mobile phases (up to $50 \%$ of bioavailable fraction) can be ranked for each site as the following in the RIR.

$$
\begin{aligned}
\mathrm{SB}: \mathrm{B} & >\mathrm{V}>\mathrm{As}>\mathrm{Mn}>\mathrm{Pb}>\mathrm{Ca}>\mathrm{Ba}>\mathrm{Co}>\mathrm{Cr}> \\
\mathrm{Fe} & >\mathrm{Zn}>\mathrm{Cu} \\
\mathrm{REG}: \mathrm{As} & >\mathrm{V}>\mathrm{Pb}>\mathrm{Mn}>\mathrm{Ca}>\mathrm{B}>\mathrm{Ba}>\mathrm{Fe}>\mathrm{Co}> \\
& \mathrm{Cr}>\mathrm{Be}
\end{aligned}
$$

Multivariate analysis results are shown in Figs. 3 and 4 as the clusters of sets of variables. Basically, this analysis showed that sediments from RIR presented similar composition, which also differed from that of
EPP (Fig.3). Chemical elements in sediments from EPP also tended to be greater associated with the residual fractions. Among the variables (Fig.4), two main clusters were formed: the first one joined the total and residual concentrations for most of elements, together with the ERFs, N, and $\mathrm{H}$ levels, and mobile phases of As and $\mathrm{Pb}$. The second cluster joined the mobile phases of the resting elements, fine particles, TOC, OM, and total concentrations of $\mathrm{Mn}, \mathrm{Pb}$, and $\mathrm{Co}$. The association of

\section{Similarity}

$\begin{array}{lllllll}0.94 & 0.95 & 0.96 & 0.97 & 0.98 & 0.991\end{array}$

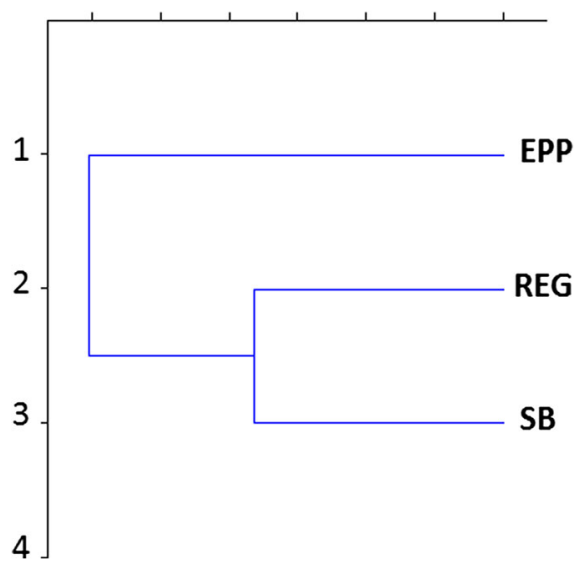

Fig. 3 Cluster analysis formed with sampling stations from the RIR (SB and REG) and the Ecological Park Perequê (EPP) 
ERFs and residual fractions is due to the low concentrations of metals detected in the sediments, and that for the majority of elements the residual fractions were predominant. Abnormalities were observed for $\mathrm{As}$ and $\mathrm{Pb}$, and despite their low concentrations (and low associated risks), these two elements are present in potentially bioavailable form. In fact, previous studies reported for bioaccumulation of $\mathrm{Pb}$ in invertebrates from RIR (Guimarães and Sígolo 2008b; Rodrigues et al. 2012), while contamination by As occurs along the basin, as this element is associated with mining residues from gold mines.

Slag from the smelting processes was characterized as sand grained (94\%) with metal concentration of $118 \mathrm{~g} / \mathrm{kg}$ of $\mathrm{Zn}$ and $34 \mathrm{~g} / \mathrm{Kg} \mathrm{Pb}$ by Guimarães and Sígolo (2008a) and $100 \mathrm{~g} / \mathrm{kg} \mathrm{Zn}$ and $28 \mathrm{~g} / \mathrm{kg} \mathrm{Pb}$ (Abessa et al. 2014) in the upper part of the basin. However, the strong rainy events disaggregate metal enriched materials that increase the chemical load of the fluvial course (Costa et al. 2009). Moraes et al. (2004) reported $90 \mathrm{mg} / \mathrm{kg}$ of $\mathrm{Pb}$ reaching the lower basin; while Guimarães and Sígolo (2008a, 2008b) also reported a decline in the concentration of $\mathrm{Pb}$ from $\mathrm{SB}$ to REG (74 and $32 \mathrm{mg} / \mathrm{kg} \mathrm{Pb}$, respectively), in contrast to findings in this study for the same stations (10 and $18 \mathrm{mg} / \mathrm{kg} \mathrm{Pb}$ ). Therefore, these temporal variations evidence about the chemical wash up of the sediments. Floods are considered the primary mechanism whereby particulate wastes are transported, and then deposited (Luoma and Rainbow 2008). Particle size might be modified due to the motion (dragging, erosion, and resuspension), and some authors observed associations between what might be explaining the association of greater textural with the lithological fraction (Guimarães and Sígolo 2008a); while most labile form are associated with finest fractions, TOC and OM (Fig.4). The results from the sequential extraction for $\mathrm{Pb}$ (Fig.2) point that transport in sediments occurs mainly bound to iron and manganese oxyhydroxides (F2 > 50\%), in agreement with Corsi and Landim (2003) findings for the upper part of the basin, whose research indicated transport of lead mainly associated with the same fraction, followed by organic matter, carbonates, and residual fraction. On the other hand, due the high mobility of $\mathrm{Pb}(\Sigma \mathrm{F}(0-3))$, this element could be released into the water column in either dissolved (F0) or particulate form (F1) or adsorbed onto iron oxides (F2). In other words, scavenging metals by colloid formation or adsorption over fines and TOC add extra surface for dissolved

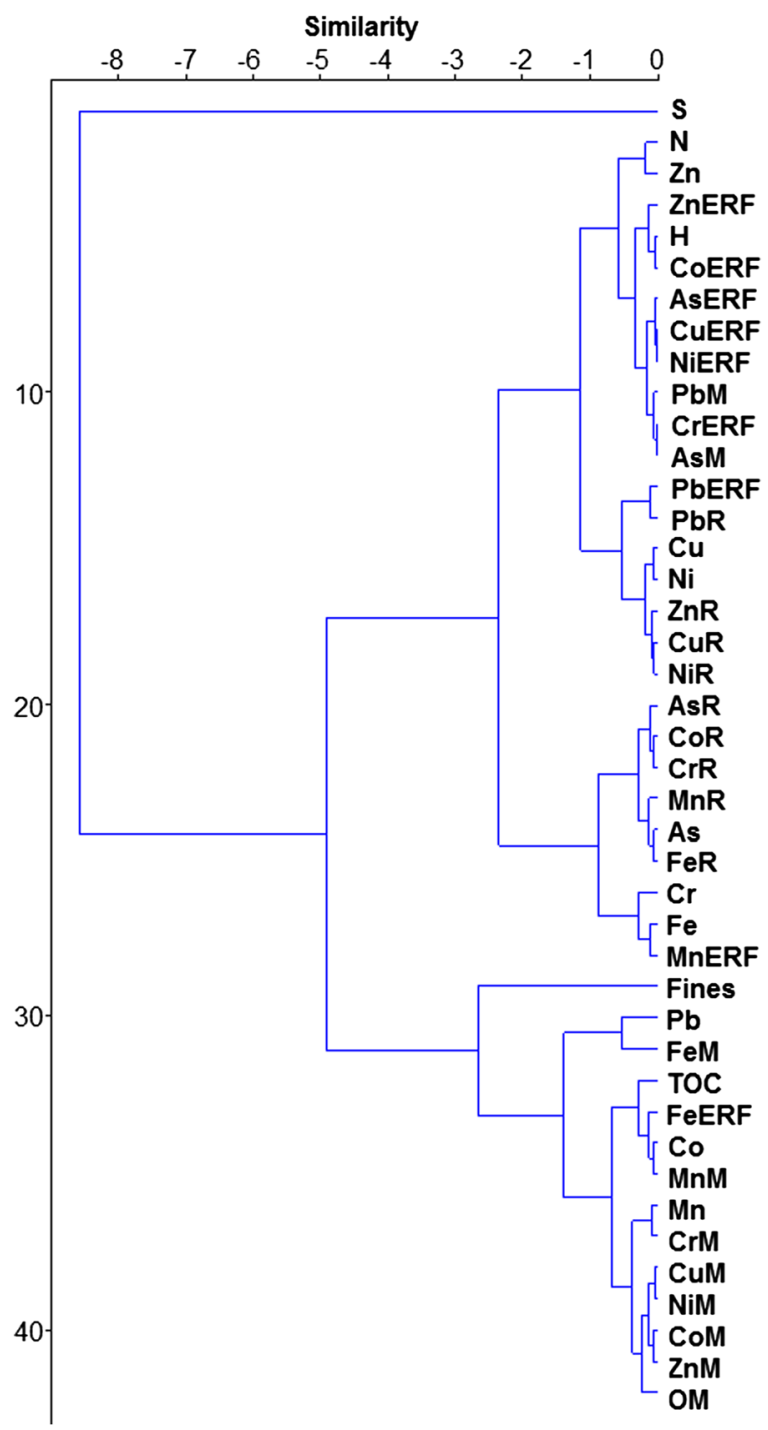

Fig. 4 Cluster analysis with the 43 variables analyzed in the sediments from RIR

metal (F3) as transporter towards the Cananéia-Iguape Estuarine Complex. Biological data gives support to our findings, as bioaccumulation of metals were observed in bivalves, and significant correlations were observed between $\mathrm{Pb}$ concentrations in sediments and in soft tissues of the bivalves Anodontites tenebricosus and Corbicula fluminea (Guimarães and Sígolo 2008b; Rodrigues et al. 2012), with higher levels being reported for the lower RIR.

There is an increase of metal concentrations and nutrients in the sediments of the RIR during the rainy season as reported by Cunha et al. (2007a, b). This is fomented by the erosion and the extra caudal supplied 
by floods; so that, the restoration of the basin in this segment it might be occurring by metal sequestration onto particulate matter that flows towards the ocean. This idea is also supported by other research studies (Moraes et al. 2004; Cunha et al. 2007a, b; Morais et al. 2013; Abessa et al. 2014). Therefore, metal content in areas close to the estuary would reflect the influences of weathering, local geology, hydrological events (floods), and inputs of upstream anthropogenic discharges (mining activities in this case).

\section{Conclusions}

Despite the former metallurgical spillages in the Vale do Ribeira, the metal concentration in the sediments from the lower basin displayed a slight risk strongly associated with the mobile phases of the geochemical matrix. The mobilization of $\mathrm{Pb}$ and its associated risk was linked with the finest fraction of the sediment in the station closest to the ocean, displacing the associated risk of the metal water downstream.

Acknowledgments The first author thanks the International Grant from Bank Santander/UNESCO Chair UNITWIN/WiCop and the Erasmus Mundus Programme for the MACOMA Doctoral funding contract (SGA 2012-1701/001-001-EMJD). We thank the Brazilian National Council for Scientific and Technological Development (CNPq; grant \#479899/2013-4), the São Paulo Research Foundation (FAPESP, grant \#2009/52762-6) and the Brazilian Aquatic Research Foundation (FUNDESPA), for the financial support. Dr. Lucas Buruaem thanks to FAPESP (grant \#13/ 15482-0, São Paulo Research Foundation), and Dr. Abessa thanks to CNPq (grants 308649/2011-7 and 311609/2014-7). Denis M.S. Abessa also acknowledges FAPESP (processes 2009/52762-6) for the financial support.

\section{References}

Abessa, D. M. S., Morais, L. G., Perina, F. C., Davanso, M. B., Buruaem, L. M., et al. (2012). Toxicidade de águas e sedimentos em um rio afetado por atividades mineradoras pretéritas. Mundo Da Saude, 36(4), 610-618.

Abessa, D. M. S., Morais, L. G., Perina, F. C., Davanso, M. B., Guimarães, V., Martins, L. M. P., \& Sígolo, J. B. (2014). Sediment geochemistry and climatic influences in a river influenced by former mining activities: the case of Ribeira de Iguape River, SP-PR, Brazil. Open Journal of Water Pollution and Treatment, 1(1), 43-53.

Bonnail, E., Sarmiento, A. M., DelValls, T. A., Nieto, J. M., \& Riba, I. (2016). Assessment of metal contamination, bioavailability, toxicity and bioaccumulation in extreme metallic environments (Iberian Pyrite Belt) using Corbicula fluminea. Science of the Total Environment, 544, 1031-1044. doi:10.1016/j.scitotenv.2015.11.131.

Buschle, B. N., Palmeiro, J. K., Youssef Bacila Sade, Y. B., Melo, V. F., Andrade, M. G., \& Batista, A. H. (2010). Cinética de liberação de chumbo de solos de área de mineração e metalurgia de metais pesados. Revista Brasileira de Ciência do Solo, 34, 1865-1874.

Charalampides, N., \& Manoliadis, O. (2002). $\mathrm{Sr}$ and $\mathrm{Pb}$ isotopes as environmental indicators in environmental studies. Environmental International, 28(3), 147-151.

Corsi, A., \& Landim, P. (2003). Chumbo, Zinco e Cobre em sedimentos de corrente nos Ribeirões Grande, Perau e Canoas, e Córrego Barrinha no município de Adrianopólis (Vale do Ribeira). Geociências, 22, 49-61.

Costa, F. H. S., Filho, C. R. S., \& Risso, A. (2009). Modelagem espaço-temporal da erosão e potencial contaminação de Arsênio e Chumbo na bacia hidrográfica do rio Ribeira de Iguape (SP). Revista Brasileira de Geociencias, 39(2), 338249.

Cunha, F. C., Paoliello, M. M. B., Figueiredo, B. R., Capitani, E. M., \& Sakuma, A. (2005). Human and environmental lead contamination in the upper Ribeira Valley southeastern Brazil. Terrae, 2, 28-36.

Cunha, D. G. F., Calijuri, M. D. C., \& Miwa, A. C. P. (2007a). A precipitação pluviométrica como agente indutor de modificações nas características químicas do sedimento do rio Jacupiranguinha, Vale do Ribeira de Iguape, SP. Revista Minerva, 4(1), 41-49.

Cunha, D. G. F., Capparelli, H., \& Calijuri, M. D. C. (2007b). Comparison between some trace and heavy metals concentrations in sediments of a river and a natural wetland system in Ribeira do Iguape Basin, São Paulo. Engenharia Ambiental, 4(1), 32-53.

Guimarães, V., \& Sígolo, J. B. (2008a). Associação de Resíduos da Metalurgia com Sedimentos em Suspensão-Rio Ribeira de Iguape. Geologia USP-Serie Cientifica, 8(2), 1-10.

Guimarães, V., \& Sígolo, J. B. (2008b). Detecção de contaminantes em espécie bioindicadora (Corbicula fluminea)-Rio Ribeira de Iguape-SP. Química nova, 31(7), 1696-1698.

Hamelink, J.L., Landrum, P.F., Harold, B.L., \& William, B.H. (1994). Bioavailability: Physical, Chemical, and Biological Interactions. Lewis Publishers. Boca Raton, FL: CRC Press Inc.

Hammer, Ø., Harper, D. A. T., \& Ryan, P. D. (2001). PAST: Palaeontological Statistics Software Package for education and data analysis. Palaeontologia Electronica, 4(1), $1-9$.

Hübner, R., Astin, K. B., \& Herbert, R. J. (2009). Comparison of sediment quality guidelines (SQGs) for the assessment of metal contamination in marine and estuarine environments. Journal of Environmental Monitoring, 11(4), 713-722. doi:10.1039/b818593j.

ISO (International Organization for Standardization) standard procedure 11466 (1995). Soil quality, extraction of trace elements soluble in aqua regia.

Kestern, M., \& Förstner, U. (1986). Chemical fractionation of heavy metals in anoxic estuarine and coastal sediments. Water Science and Technology, 18, 121-130. 
Lopes, Jr.I. (2007). Atlas geoquímico do Vale do Ribeira: geoquímica dos sedimentos ativos de corrente / Idio Lopes Jr.2. ed. rev. São Paulo: CPRM, 2007.

Luoma, S. N., \& Davis, J. A. (1983). Requirements for modeling trace metal partitioning in oxidized estuarine sediments. Marine Chemistry, 12, 159-181.

Luoma, S.N., \& Rainbow, P.S. (2008). Metal contamination in aquatic environments. Science and lateral management. Cambridge university press.

Mooi, E., \& Sarstedt, M. (2011). A concise guide to market research. The process, data, and methods using IBM SPSS statistics. Berlin: Springer-Verlag 308p.

Moraes, R. P., Figueiredo, B. R., \& Lafon, J. (2004). Pb-isotopic tracing of metal-pollution sources in the Ribeira Valley, Southeastern Brazil. Terrae, 1(1), 26-33.

Morais, L. G., Perina, F. C., Davanso, M. B., Buruaem, L. M., Rodrigues, V. G. S., Sígolo, J. B., \& Abessa, D. M. S. (2013). Water and sediment ecotoxicological assessment in a river affected by former mining activities. Pan American Journal of Aquatic Sciences, 8(4), 327-338.

Nakata, H., Nakayama, S. M., Oroszlany, B., Ikenaka, Y., et al. (2017). Monitoring lead $(\mathrm{Pb})$ pollution and identifying $\mathrm{Pb}$ pollution sources in Japan using stable $\mathrm{Pb}$ isotope analysis with kidneys of wild rats. International Journal of Environmental Research and Public Health, 14(1). doi:10.3390/ijerph14010056.

Pérez-López, R., Álvarez-Valero, A. M., Nieto, J. M., Sáez, R., \& Matos, J. X. (2008). Use of sequential extraction procedure for assessing the environmental impact at regional scale of the São Domingos Mine (Iberian Pyrite Belt). Applied Geochemistry, 23(12), 3452-3463. doi:10.1016/j. apgeochem.2008.08.005.

Pluta, B. (2006). Freshwater sediment screening benchmarks: hierarchy for selection of freshwater sediment benchmarks. From the US EPA. http://www.epa.gov/risk/freshwatersediment-screening-benchmarks.

Riba, I., DelValls, T. A., Forja, J. M., \& Gómez-Parra, A. (2002a). Influence of the Aznalcóllar mining spill on the vertical distribution of heavy metals in sediments from the Guadalquivir estuary (SW Spain). Marine Pollution Bulletin, 44, 39-47.

Riba, I., DelValls, T. A., Forja, J. M., \& Gómez-Parra, A. (2002b). Monitoring the impact of the Aznalcóllar mining spill on recent sediments from the Guadalquivir estuary, Southwest Spain. Bulletin of Environmental Contamination and Toxicology, 69, 129-138. doi:10.1007/s00128-002-0019-4.

Rodrigues, V. G. S., Fujikawa, A., Abessa, D. M. S., Hortellani, M. A., Sarkis, J. E. S., \& Sígolo, J. B. (2012). Uso do bivalve límnico Anodontites tenebricosus (Lea, 1834) no biomonitoramento de metais do Rio Ribeira de Iguape. Quimica Nova, 35, 454-459.

Tessier, A., Campbell, P. G. C., \& Blsson, M. (1979). Sequential extraction procedure for the speciation of particulate trace metals. Analytical Chemistry, 51(7), 844-851.

Vives, A., Brienza, S., Moreira, S., Zucchi, O., Barroso, R., \& Filho, V. (2007). Evaluation of the availability of heavy metals in lake sediments using SR-TXRF. Nuclear Instrumentation Methods, 579, 503-506. 